\title{
Piotr Czarny
}

\section{Ocena art. 25 ustawy o finansowaniu zadań oświatowych ${ }^{1}$}

Evaluation of Article 25 of the Act on Financing Educational Tasks: The opinion refers to the allegation that Article 25 of the act introduces different treatment of public schools run by local self-government units and public schools run by other entities. Running a public school is the most important feature in terms of entitlement to receive subsidies from the state budget and budgets of local self-government units. As to the amount of the subsidy (and the method of its calculation), the question of the legal status of the entity running a school is an important issue. Public schools run by local government units are budgetary units of the public finance sector. Budgetary units are subject to various restrictions, which do not apply to other entities. It cannot be a priori recognized that the financing schools in both cases must be based on absolutely the same - in formal terms - principles. Criterion provided by Article 25 para. 3 of the Act causes that a certain type of public post-secondary schools, in which there is no compulsory schooling or the obligation to learn, is treated like schools for adults, despite the fact that it belongs to other types of such institutions. The introduced diversity is therefore inadequate to the motive of its establishment indicated in the course of legislative works.

\author{
Keywords: subsidies | education | public finance | constitution | education | \\ local self-government | school \\ Słowa kluczowe: dotacje | edukacja | finanse publiczne | konstytucja | oświata | \\ samorząd terytorialny | szkoła
}

Doktor nauk prawnych, starszy wykładowca na Uniwersytecie Jagiellońskim, ekspert ds. legislacji BAS; piotr.czarny@neostrada.pl.

\section{Zagadnienia wstępne}

1. Przedmiotem niniejszej opinii prawnej jest analiza problemu wskazanego w skierowanym do Marszałka Sejmu piśmie dyrektor Publicznej Zaocznej Po-

1 Opinia prawna $w$ sprawie art. 25 ustawy o finansowaniu zadań oświatowych sporządzona 6 grudnia 2017 r. na zlecenie zastępcy Szefa Kancelarii Sejmu; BAS-WAKiU 2293/17. 
licealnej Szkoły Informatyki Cosinus w Łodzi z 27 października 2017 r. Podniesiono w nim, że art. 25 projektu ustawy o finansowaniu zadań oświatowych wprowadza różne traktowanie szkół publicznych prowadzonych przez jednostki samorządu terytorialnego i szkół publicznych prowadzonych przez inne podmioty. Wskazano w nim, że status prawny podmiotu prowadzącego dany typ szkoły nie ma znaczenia dla „kosztów organizacji nauki”. Co więcej, z przyczyn praktycznych koszty „utrzymania jednego słuchacza” są w szkołach publicznych prowadzonych przez jednostki samorządu terytorialnego $\mathrm{w}$ wielu przypadkach niższe niż w szkołach prowadzonych przez inne podmioty. Stąd też - w ocenie autorki pisma - proponowane rozwiązanie stanowi przejaw dyskryminacji szkół prowadzonych przez inne podmioty niż jednostki samorządu terytorialnego. Dodano też, że uzasadnienie projektu nie wskazuje, dlaczego zaproponowano zróżnicowanie zasad dotowania szkół publicznych w zależności od podmiotu, który jej prowadzi.

2. Kwestią wstępną o charakterze proceduralnym jest zagadnienie prawnej kwalifikacji pisma dyrektor Publicznej Zaocznej Policealnej Szkoły Informatyki Cosinus w Łodzi i sposobu ewentualnego rozpatrzenia sprawy w nim poruszonej. Pismo to trudno uznać za petycję, ponieważ zgodnie z art. 2 ust. 3 ustawy z 11 lipca 2014 r. o petycjach (t.j. Dz.U. 2017, poz. 1123): [p]rzedmiotem petycji może być żądanie, $w$ szczególności, zmiany przepisów prawa, podjęcia rozstrzygnięcia lub innego działania $w$ sprawie dotyczacej podmiotu wnoszącego petycje, życia zbiorowego lub wartości wymagających szczególnej ochrony w imię dobra wspólnego, mieszczacych się w zakresie zadań i kompetencji adresata petycji. Tymczasem w piśmie dyrektor Publicznej Zaocznej Policealnej Szkoły Informatyki Cosinus w Łodzi nie sformułowano wprost żadnych „żądań” pod adresem władz publicznych.

Jego treść sugeruje raczej, że mamy tu do czynienia ze skargą, której przedmiotem jest (potencjalne) naruszenie praworządności (a konkretnie naruszenie Konstytucji RP) i interesów skarżącego. Zgodnie z art. 240 Kodeksu postępowania administracyjnego, gdy skarga dotyczy sprawy, która nie podlega rozpatrzeniu według przepisów Kodeksu (art. $3 \$ 1$ i 2 ) albo nie należy do właściwości organów administracji publicznej (a taki charakter ma sprawa podniesiona w piśmie z 27 października 2017 r.), przepisy art. 233-239 stosuje się odpowiednio, z zastrzeżeniem, że w miejsce pozostałych przepisów Kodeksu stosuje się przepisy postępowania właściwego dla danej sprawy. Jednak przepisy Konstytucji RP, ustaw i regulaminu Sejmu dotyczące postępowania ustawodawczego nie regulują w żaden sposób kwestii składania i rozpatrywania skarg.

3. Poza tym zauważyć należy, że od momentu złożenia wskazanego pisma $\mathrm{w}$ istotny sposób zmienił się stan faktyczny sprawy w nim podniesionej. Po pierwsze, rządowy projekt ustawy o finansowaniu zadań oświatowych został uchwalony przez Sejm 27 października 2017 r. Ponieważ Senat nie wniósł poprawek, ustawa została 13 listopada 2017 r. przekazana Prezydentowi do pod- 
pisu $^{2}$. Prezydent podpisał tę ustawę i została ona 29 listopada 2017 r. ogłoszona w Dzienniku Ustaw pod poz. 22033.

W tej sytuacji czynnością, którą ewentualnie mógłby podjąć Marszałek Sejmu, wydaje się przekazanie pisma, o którym mowa wyżej, Komisji Edukacji, Nauki i Młodzieży w celu rozważenia zasadności podniesionych w nim argumentów i możliwości wystąpienia z inicjatywą nowelizacji ustawy o finansowaniu zadań oświatowych. Marszałek Sejmu ma jednak również uprawnienie do wystąpienia do Trybunału Konstytucyjnego z wnioskiem o stwierdzenie niezgodności ustawy z Konstytucją.

Po drugie, w toku prac ustawodawczych treść art. 25 ustawy o finansowaniu zadań oświatowych - a konkretnie jego ust. 3 - uległa istotnym zmianom. Stąd też analizowanie i ocena treści samego projektu tej ustawy w tym zakresie nie ma w chwili obecnej praktycznego znaczenia w odniesieniu do szkół publicznych, w których nie jest realizowany obowiązek szkolny lub obowiązek nauki, które nie są szkołami specjalnymi.

4. Niezależnie od powyższych uwag proceduralnych w dalszej części pisma przedstawiono merytoryczną stronę podniesionego w piśmie dyrektor Publicznej Zaocznej Policealnej Szkoły Informatyki Cosinus w Łodzi problemu, przy założeniu, że analiza ta ma skrócony charakter. Z uwagi na to, że szkoła ta jest publiczną szkołą policealną, badanie ograniczono w zasadzie do tego typu szkół. Z góry zastrzec należy, że rozważania te nie mają charakteru wyczerpującego, co wiąże się z tym, że ocena zgodności określonej regulacji ustawowej z konstytucyjną zasadą równości i zakazem dyskryminacji wymagałaby w tym przypadku analizy finansowych konsekwencji art. 25 ustawy o finansowaniu zadań oświatowych, co - wobec skomplikowania problematyki - wymaga specjalistycznej wiedzy z zakresu prawa oświatowego i prawa finansowego, jak również z zakresu praktyki funkcjonowania szkół publicznych.

\section{Uzasadnienie i ustalenia szczegółowe}

1. Punktem wyjścia dla dalszych rozważań jest treść art. 25 ust. 3 rządowego projektu ustawy o finansowaniu zadań oświatowych (druk sejmowy nr 1837). Zgodnie z nim: prowadzone przez osoby prawne niebędace jednostkami samorzadu terytorialnego oraz osoby fizyczne publiczne szkoły, w których nie jest realizowany obowiązek szkolny lub obowiązek nauki, niebędace szkołami specjalnymi otrzymują na każdego ucznia dotację z budżetu jednostki samorządu terytorialnego będacej dla tych szkół organem rejestrującym, w wysokości stanowiącej iloczyn kwoty

2 Http://www.sejm.gov.pl/Sejm8.nsf/PrzebiegProc.xsp?id=56F5B3373F0E5251C12581 A200460E8E [dostęp 21 listopada 2017 r.].

3 Http://dziennikustaw.gov.pl/du/2017/2203/1. 
przewidzianej na takiego ucznia w części oświatowej subwencji ogólnej dla jednostki samorządu terytorialnego oraz wskaźnika zwiększającego dla szkół danego typu niebędacych szkołami specjalnymi. Szkoły publiczne prowadzone przez osoby prawne niebędące jednostkami samorządu terytorialnego oraz osoby fizyczne określane są skrótowo mianem niesamorządowych szkół publicznych. Nie wnikając w szczegóły, wskazać trzeba, że podobne zasady w zakresie finansowania dotyczyć miały również niesamorządowych szkół publicznych innych typów. Przypomnieć też należy, że niesamorządowe szkoły publiczne to inna instytucja niż szkoły prywatne o uprawnieniach szkół publicznych. Podstawowa różnica polega na tym, że w tych pierwszych nauka jest bezpłatna, a w drugich nie.

Idea ogólna przytoczonego rozwiązania polegała na tym, że niesamorządowe szkoły publiczne otrzymują dotację zależną od dwóch elementów. Pierwszym jest kwota „na ucznia” przewidziana w części oświatowej subwencji z budżetu państwa dla jednostek samorządu terytorialnego. Ten element powinien być równy dla wszystkich typów szkół publicznych. Drugi element, tj. współczynnik zwiększający, uwzględnia to, że jednostki samorządu terytorialnego finansują działalność prowadzonych przez siebie szkół również „ze środków własnych”, tj. ponad kwoty wynikające z subwencji z budżetu państwa. Chodzi więc w założeniu o to, żeby wszystkie szkoły publiczne były traktowane równo, a szkoły prowadzone przez jednostki samorządu terytorialnego nie były z założenia w lepszej sytuacji finansowej z uwagi na otrzymywanie środków publicznych od prowadzących je jednostek ponad kwoty wynikające z wysokości kwot przekazywanych z budżetu państwa.

Istota proponowanej zmiany widoczna jest w zestawieniu $\mathrm{z}$ jeszcze obowiązującym art. 80 ust. 3ae ustawy z 7 września 1991 r. o systemie oświaty (t.j. Dz.U. 2016, poz. 1943, ze zm.), zgodnie z którym: [p]rowadzone przez osoby prawne niebędace jednostkami samorzadu terytorialnego lub osoby fizyczne publiczne szkoły niewymienione $w$ ust. 3 otrzymuja na każdego ucznia dotacje $z$ budzetu jednostki samorządu terytorialnego obowiązanej do prowadzenia danego typu i rodzaju szkół w wysokości równej podstawowej kwocie dotacji dla szkót danego typu i rodzaju, nie niższej jednak niż kwota przewidziana na takiego ucznia w części oświatowej subwencji ogólnej dla jednostki samorządu terytorialnego.

W projekcie założono więc faktycznie zmianę systemu finansowania szkół publicznych prowadzonych przez osoby niebędące jednostkami samorządu terytorialnego. W uzasadnieniu projektu i dołączonych do niego materiałach wyjaśniono cel proponowanej zmiany. Wskazano tam, że: [z] miany $w$ zakresie dotowania niepublicznych, jak i publicznych placówek wychowania przedszkolnego, szkót i placówek prowadzonych przez ministrów, osoby prawne niebędące jednostkami samorzadu terytorialnego oraz osoby fizyczne polegaja głównie na odejściu od pojęcia rodzaju szkoły przy wyliczaniu dotacji dla szkół (s. 8). Wyjaśniono też, że w projekcie: [w]prowadzono definicję wskaźnika zwiększającego dla szkót danego typu, niebędących szkołami specjalnymi (art. 14 ust. 1 projektu ustawy) 
oraz wskaźnika zwiększającego dla szkół danego typu będących szkołami specjalnymi (art. 14 ust. 2 projektu ustawy). Wprowadzenie powyższego wskaźnika jest konieczne, aby w przypadku dotowanych szkół publicznych odpowiednio zwiększyć kwote przeznaczona w części oświatowej subwencji ogólnej dla jednostki samorzadu terytorialnego na ucznia, uwzględniając wszystkie wydatki ponoszone przez ten samorząd na szkoły danego typu (ponad kwotę naliczana w części oświatowej subwencji ogólnej) (s. 10).

Dodatkowo przytoczyć należy dwa fragmenty z dołączonego do uzasadnienia raportu z konsultacji, w którym za wyjaśnione uznano uwagi polegające na tym, że: przepisy dotyczace dotacji z JST [jednostek samorządu terytorialnego dopisek P.C.] dla szkół i placówek prowadzonych przez inne podmioty niż JST sq skomplikowane i moga spowodować obniżenie dotacji dla tych podmiotów. Wskazano, iż: w przypadku szkót publicznych kwota w subwencji oświatowej zostanie odpowiednio zwiększona przez przemnożenie jej przez tzw. wskaźnik zwiększający. Wskaźnik zwiększający uwzględnia rzeczywiste wydatki danego samorzadu na dany typ szkoły przez określenie, jaki procent dany samorzad wydaje ponad subwencje (tj. iloraz rzeczywistych poniesionych wydatków $w$ danym samorządzie na dany typ szkoły do kwoty subwencji otrzymanej na te szkoły). Przemnożenie kwoty subwencji przez wskaźnik zwiększający umożliwi więc odniesienie kwoty dotacji do rzeczywistych wydatków ponoszonych przez samorzad na dany typ szkoły. Intencja ustawodawcy jest dotowanie szkó publicznych niesamorządowych $w$ takiej samej kwocie na ucznia jak wydatki na ucznia ponoszone przez samorzad w szkołach samorządowych (raport z konsultacji, s. 45).

Mówiąc najkrócej, proponowana zmiana nie polegała na tym, aby niesamorządowe szkoły publiczne finansowane były wyłącznie w wysokości wynikającej z subwencji „na ucznia” pochodzącej z budżetu państwa, ale na przyjęciu innej metody określenia swego rodzaju „dodatku”, wynikającego z założenia, że samorząd terytorialny winien w równym stopniu przyczyniać się do zapewnienia „środków pieniężnych” na działalność wszystkich szkół publicznych należących do określonego typu placówek bez względu na podmiot je prowadzący.

2. Oceniając całe zagadnienie z konstytucyjnego punktu widzenia, stwierdzić należy, że w świetle orzecznictwa Trybunału Konstytucyjnego zasada równości nie oznacza, że istnienie odmiennego traktowania adresatów norm prawnych charakteryzujących się wspólną cechą istotną jest zawsze jej naruszeniem czy też dyskryminacją. Konieczna w takiej sytuacji jest ocena kryterium, na podstawie którego dokonano zróżnicowania. Jak stwierdził TK w wyroku z 6 maja 1998 r., sygn. akt K 37/97: [z]asada równości zakłada jednocześnie różne traktowanie podmiotów różnych, tj. podmiotów, które nie posiadaja wspólnej cechy istotnej. Równość wobec prawa to zasadność wyboru takiego, a nie innego kryterium różnicowania. Aby odpowiedzieć na pytanie, czy dane kryterium może stanowić podstawę różnicowania podmiotów prawa, należy rozstrzygnać: czy kryterium to pozostaje $w$ racjonalnym związku z celem i treścia danej regulacji; czy waga in- 
teresu, któremu różnicowanie ma służyć pozostaje $w$ odpowiedniej proporcji do wagi interesów, które zostana naruszone w wyniku wprowadzonego różnicowania; czy kryterium różnicowania pozostaje w związku z innymi wartościami, zasadami, czy normami konstytucyjnymi, uzasadniajacymi odmienne traktowanie podmiotów podobnych (orzeczenia: z 3 września 1996 r., K. 10/96, OTK ZU Nr 4(7)/1996, s. 280-281, z 16 grudnia 1996 r., U. 1/96, OTK ZU Nr 6(9)/1996, s. 530 i n.). $\mathrm{W}$ analizowanej w niniejszej opinii sprawie stwierdzić można, że prowadzenie (utrzymywanie) szkoły publicznej jest najważniejszą cechą istotną w zakresie uprawnienia do otrzymywania dotacji ze środków z budżetu państwa i budżetów jednostek samorządu terytorialnego. Jednakże, jeśli chodzi o wysokość dotacji (i sposób jej obliczenia), to kwestia statusu prawnego podmiotu prowadzącego nie jest zagadnieniem nieistotnym. W tym kontekście zauważyć należy, że szkoły publiczne prowadzone przez jednostki samorządu terytorialnego są jednostkami budżetowymi sektora finansów publicznych, a szkoły publiczne prowadzone przez inne podmioty nie. Jednostki budżetowe podlegają różnego rodzaju ograniczeniom, które nie dotyczą innych podmiotów. Utrzymywanie szkół stanowi realizację ustawowych zadań jednostek samorządu terytorialnego w zakresie edukacji publicznej, a w przypadku innych podmiotów jest to konkretyzacja prawa do zakładania szkół podstawowych i ponadpodstawowych (art. 70 ust. 3 Konstytucji). Stąd też nie można a priori uznać, że finansowanie szkół w obu tych przypadkach musi być oparte na absolutnie takich samych - pod względem formalnym - zasadach. Zwrócić należy też uwagę, że wielkość kwot, jakie jednostki samorządu przeznaczają na funkcjonowanie prowadzonych przez siebie szkół, nie jest określona w sposób absolutnie „sztywny”. W ramach przysługującej im samodzielności (art. 165 ust. 2 Konstytucji) mogą one przeznaczać na funkcjonowanie placówek oświatowych kwoty wyższe niż minimum wynikające z przepisów ustawowych. Realizacja zasady równego traktowania szkół publicznych musi uwzględniać w tym wypadku samodzielność samorządu terytorialnego, co oznacza wręcz konieczność wprowadzenia odrębnych reguł dla szkół niesamorządowych. Reguły te z formalnego punktu widzenia tworzą zróżnicowanie, ale ma ono charakter tzw. zróżnicowania wyrównawczego. To zaś jest realizacją zasady równości, a nie jej naruszeniem.

Poza tym zauważyć należy, że najistotniejszym aspektem realizacji zasady równości w zakresie prawa oświatowego powinno być dążenie do równego traktowania uczniów jako osób, które korzystają z prawa do nauki, w szczególności zaś zapewnienia im „równego dostępu do wykształcenia” (art. 70 ust. 4 Konstytucji).

Co do konstytucyjnoprawnego uzasadnienia zmian proponowanych w art. 25 ust. 3 projektu ustawy o finansowaniu zadań oświatowych dodać należy, że zgodnie z orzecznictwem Trybunału Konstytucyjnego kryterium, które stanowi podstawę zróżnicowania, powinno być tzw. kryterium operatywnym. Chodzi o to, aby organ posługujący się tym kryterium, dokonujący m.in. na jego podstawie subsumpcji i podejmujący następnie rozstrzygnięcie, nie miał trudności z odpo- 
wiedzią na pytanie, czy w danym przypadku podmiot spełnia ustawowe kryterium, czy też go nie spełnia.

Jak wynika z orzeczenia TK z 27 czerwca 1995 r., sygn. akt K 4/94: [w] procesie tworzenia prawa występuje prawidłowość polegająca na tym, że im bardziej próbuje się sprecyzować kryterium, w oparciu o które dokonujemy zróżnicowania, tym trudniejsze może być ustalenie, kto spełnia wymogi przewidziane w przepisie. Tak więc dążenie do zachowania w jak największym stopniu równości i sprawiedliwości na płaszczyźnie generalno-abstrakcyjnej może w praktyce spowodować niemożność posługiwania się danym kryterium na płaszczyźnie konkretno-indywidualnej. Wymagać ono będzie bowiem ustalenia elementów sytuacji faktycznej o takim stopniu szczegółowości, któremu organ nie będzie w stanie sprostać. Przyjęcie tego rodzaju kryterium godzi w konstytucyjna zasadę równości $w$ ten sposób, iz uniemożliwia w praktyce zachowanie równości na płaszczyźnie stosowania prawa. $Z$ powyższego wynika, iż możliwość doboru kryteriów i ich precyzowania w ustawie podlega praktycznym ograniczeniom.

Stwierdzenia powyższe pasują do analizowanego tu problemu w tym sensie, że zarysowane wcześniej obowiązujące uregulowania nie spełniały - jak wynika z uzasadnienia projektu - kryterium operatywności, mimo podejmowanych wiele razy prób ich doprecyzowania. Powodowały cały czas wątpliwości interpretacyjne, związane głównie z wykładnią pojęcia „rodzaj szkoły”. Stąd też uzasadniona w świetle Konstytucji RP była ich zmiana i oparcie systemu obliczania dotacji na innej metodzie.

Wcześniejsze rozważania dotyczyły wyłącznie „strony formalnej” całego zagadnienia, tj. samej dopuszczalności wprowadzenia nowych metod obliczania dotacji dla niesamorządowych szkół publicznych. Ocena, czy nie powoduje to faktycznych skutków finansowych niekorzystnych dla tej grupy podmiotów w porównaniu ze szkołami samorządowymi, i to skutków nieproporcjonalnych do zarysowanych wcześniej różnic w ich statusie prawnym, wymagałaby szczegółowej analizy art. 14 projektu ustawy o finansowaniu zadań oświatowych i metod obliczania tzw. wskaźników zwiększających. Z uwagi na to, że zasadniczy wskaźnik zwiększający uzależniony jest od aż 10 czynników, konieczne byłoby przygotowanie odrębnego opracowania z wykorzystaniem szczegółowej wiedzy z zakresu prawa oświatowego i prawa finansowego. Dopiero ustalenia takie mogłyby stać się podstawą pełnej oceny pod względem zgodności z Konstytucją RP.

3. W ostatecznie przyjętym przez Sejm brzmieniu art. 25 ust. 3 przewiduje, że: [p] rowadzone przez osoby prawne niebędace jednostkami samorzadu terytorialnego oraz osoby fizyczne publiczne szkoły, w których nie jest realizowany obowiązek szkolny lub obowiązek nauki, niebędące szkołami specjalnymi otrzymuja na każdego ucznia dotacje z budżetu jednostki samorządu terytorialnego będacej dla tych szkół organem rejestrującym, w wysokości równej kwocie przewidzianej na takiego ucznia w części oświatowej subwencji ogólnej dla jednostki samorządu terytorialnego. 
Jak łatwo zauważyć, różnica w stosunku do proponowanej przez rząd metody obliczania dotacji polega na zniesieniu zastosowania w tym wypadku tzw. wskaźnika zwiększającego. Nowe brzmienie art. 25 ust. 3 wprowadzone zostało $\mathrm{w}$ wyniku poprawki poselskiej zgłoszonej w trakcie drugiego czytania projektu. Jak wskazano na wspólnym posiedzeniu Komisji Edukacji, Nauki i Młodzieży oraz Komisji Samorządu Terytorialnego i Polityki Regionalnej w dniu 26 października 2017 r., propozycja autorów poprawki w ustawie o finansowaniu zadań oświatowych polegała na tym, aby: $w$ poprawce $n r 6-w$ art. $25 w$ ust. 3 wyrazy „w wysokości stanowiącej iloczyn kwoty przewidzianej na takiego ucznia w czesści oświatowej subwencji ogólnej dla jednostki samorządu terytorialnego oraz wskaźnika zwiększającego, o którym mowa $w$ art. 14 ust. 1” zastąić wyrazami „w wysokości równej kwocie przewidzianej na takiego ucznia w części oświatowej subwencji ogólnej dla jednostki samorząu terytorialnego. Intencję poprawki lapidarnie wyjaśniła obecna na posiedzeniu minister edukacji, stwierdzając, że: [c]hodzi o to, że mówimy o tym, aby przy wyliczaniu dotacji w szkołach publicznych dla dorostych niebędacych szkołami specjalnymi odnosić się jedynie do kwoty przewidzianej w subwencji oświatowej, tj. bez uwzględnienia wskaźnika zwiększajacego ${ }^{4}$.

Nawiązując do wcześniejszych rozważań, należy stwierdzić, że przyjęta poprawka oznacza, iż niesamorządowe szkoły publiczne, w których nie jest realizowany obowiązek szkolny lub obowiązek nauki, będą finansowane ze środków publicznych wyłącznie w wysokości określonej przez kwotę przewidzianą na ucznia w części oświatowej subwencji ogólnej. Natomiast nie będzie dopuszczalne uwzględnienie w kwocie dotacji dla nich rzeczywistych wydatków ponoszonych przez samorząd na prowadzenie przez siebie szkół tego „rodzaju”. Mamy tu do czynienia z „podwójnym” zróżnicowaniem. Po pierwsze, opisane wcześniej szkoły prowadzone przez jednostki samorządu terytorialnego będą (mogą być) „faworyzowane”. Jednostki samorządu terytorialnego będą mogły przeznaczać na ich utrzymanie środki finansowe bez konieczności uwzględnienia, że powodować to będzie - poprzez zastosowanie wskaźnika zwiększającego obowiązek zwiększenia dotacji dla szkół publicznych prowadzonych przez inne podmioty. Po drugie, w samej kategorii niesamorządowych szkół publicznych dochodzi do zróżnicowania. Tego rodzaju placówki, w których jest realizowany obowiązek szkolny lub obowiązek nauki albo są szkołami specjalnymi, będą bowiem otrzymywały dotację z uwzględnieniem wskaźników zwiększających, a pozostałe - bez uwzględnienia tych wskaźników. Trudno wskazać racjonalne uzasadnienie tak daleko idącego zróżnicowania, tym bardziej że oddziałuje ono pośrednio na realizację konstytucyjnej gwarancji dla zapewnienia równego dostępu do wykształcenia (art. 70 ust. 4 Konstytucji). Tej gwarancji nie można rozumieć wyłącznie w sposób formalny, jako „dostępu do instytucji oświatowych”.

4 Zob. zapis przebiegu posiedzenia komisji, 26 października 2017 r., http://www.sejm. gov.pl/Sejm8.nsf/biuletyn.xsp?skrnr=ENM-113 [dostęp 20 listopada 2017 r.]. 
Wykształcenie oznacza bowiem: wiadomości i umiejętności zdobyte w szkole lub na studiach, umożliwiajace wykonywanie jakiegoś zawodu. Wysokość dotacji na działalność placówki oświatowej z natury rzeczy oddziałuje na zakres i sposób przekazywania w niej „wiadomości i umiejętności”. Obniżenie dotacji na działalność pewnego typu placówek nie jest oczywiście niedopuszczalne, ale jednym z warunków jest zachowanie zasady, zgodnie z którą nie prowadzi to w konsekwencji do odmiennego traktowania przez władze publiczne uczniów szkół analogicznych typów.

Poza tym przyjęta regulacja zrównuje właściwie w zakresie finansowania ze środków publicznych niesamorządowe szkoły publiczne, w których nie jest realizowany obowiązek szkolny lub obowiązek nauki, i analogiczne typy szkół prywatnych o uprawnieniach szkół publicznych. Zgodnie bowiem z art. 26 ust. 2 ustawy o finansowaniu zadań oświatowych: [s]zkoły niepubliczne, w których nie jest realizowany obowiązek szkolny lub obowiązek nauki, otrzymuja na każdego ucznia uczestniczacego w co najmniej 50\% obowiązkowych zajęć edukacyjnych $w$ danym miesiacu dotacje $z$ budżetu jednostki samorzadu terytorialnego [...] $w$ wysokości równej kwocie przewidzianej na takiego ucznia w części oświatowej subwencji ogólnej dla jednostki samorząu terytorialnego. Przyjęta regulacja zaciera więc dodatkowo podstawową różnicę w systemie finansowania obu tych typów szkół, jaką jest bezpłatny lub odpłatny charakter nauki.

Jak już wspomniano, konstytucyjna zasada równości nie zakłada zakazu zróżnicowania podmiotów stosunków prawnych, nawet jeżeli legitymują się określoną wspólną cechą. Wówczas jednak wykazać należy, że - ujmując rzecz krótko - zróżnicowanie jest racjonalnie uzasadnione, ma swoje oparcie w normach, zasadach i wartościach konstytucyjnych i „sprawiedliwe” (tj. głównie proporcjonalne do występujących różnic).

$\mathrm{Z}$ tego punktu widzenia zauważyć należy, że trudno w ogóle ustalić, jaki był cel uregulowania przyjętego w art. 25 ust. 3, a zatem i podstawa faktyczna kryterium zróżnicowania. O kryterium tym można powiedzieć, że jest merytorycznie związane z przedmiotem regulacji i ma charakter operatywny (jednoznaczny). Na podstawie powszechnie dostępnych źródeł nie można ustalić, jakie dokładnie były podstawy (motywy) wprowadzonego (i, jak podkreślono wcześniej, wieloaspektowego) zróżnicowania. Stąd też nie można uznać, że spełniają one konstytucyjne standardy, w szczególności zaś, że odpowiadają zasadom sprawiedliwości społecznej i zasadzie proporcjonalności.

Co do celu regulacji, to wątpliwości pogłębia dodatkowo ich motywacja, przy czym problematyczna jest nie tylko jej lakoniczność. Przede wszystkim chodzi o to, że pojęcie szkół dla dorosłych, do których - zgodnie z wcześniej przytoczoną wypowiedzią - odnosić się miała zgłoszona w toku prac w Sejmie poprawka nie pokrywa się z określeniem: szkoły publiczne, w których nie jest realizowany

5 Słownik języka polskiego, t. VI, Warszawa 2007, s. 158. 
obowiązek szkolny lub obowiązek nauki. Szkoła dla dorosłych jest bowiem szkołą, o której mowa w art. 18 ust. 1 pkt 1 i 2 lit. a i f ustawy z 14 grudnia 2016 r. Prawo oświatowe (Dz.U. 2017, poz. 59, ze zm.), a więc taką, w której stosuje się odrębną organizację kształcenia i do której są przyjmowane osoby mające 18 lat, a także kończące 18 lat w roku kalendarzowym, w którym są przyjmowane do szkoły. Istotne dla statusu szkół dla dorosłych jest to, że kształcenie odbywać się może (ale nie musi) w formie zaocznej (art. 98 ust. 1 pkt 15 ustawy - Prawo oświatowe). Szkoły dla dorosłych nie są poza tym zobowiązane do prowadzenia zajęć wychowania fizycznego (art. 28 ust. 2 ustawy - Prawo oświatowe). Nie wnikając w szczegóły, wskazać też należy, że zajęcia ze słuchaczami w szkole dla dorosłych kształcącej w formie stacjonarnej odbywają się przez 3 lub 4 dni w tygodniu, a w formie zaocznej konsultacje zbiorowe odbywają się zasadniczo we wszystkich semestrach co 2 tygodnie przez 2 dni (zob. $\$ 20$ rozporządzenia Ministra Edukacji Narodowej z 17 marca 2017 r. w sprawie szczegółowej organizacji publicznych szkół i publicznych przedszkoli, Dz.U. poz. 649). Wobec tych różnic w porównaniu z innymi szkołami można byłoby ewentualnie zastanawiać się, czy istotnie wobec szkół dla dorosłych uzasadnione jest stosowanie nieco innych zasad finansowania, szczególnie dla placówek kształcących w formie zaocznej, ale trudno wskazać powody, dla których w daleko idący sposób zasadne jest różnicować szkoły samorządowe i niesamorządowe.

Na marginesie należy wskazać, że formułowane często oceny, dotyczące różnego rodzaju nieprawidłowości w dotowaniu szkół dla dorosłych, odnoszą się głównie do szkół niepublicznych. Jak stwierdziła Najwyższa Izba Kontroli: [w] obowiązującym systemie organizacji kształcenia osób dorostych nie funkcjonuja mechanizmy, które zapewniałyby wysoka jakość, skuteczność i efektywność ksztatcenia. Przyjęte rozwiąania nie zapobiegaja zjawiskom patologicznym, w tym wyłudzaniu dotacji przez część szkół niepublicznych ${ }^{6}$. Trudno więc uzasadnić wprowadzoną zmianę potrzebą eliminacji zjawisk patologicznych.

4. Dodatkowy problem polega na tym, że w świetle uchwalonej przez Sejm ustawy o finansowaniu zadań oświatowych szkołą, w której nie jest realizowany obowiązek szkolny lub obowiązek nauki, jest szkoła podstawowa dla dorosłych, liceum ogólnokształcące dla dorosłych i szkoła policealna (art. 2 pkt 30). Jak $\mathrm{z}$ tego wynika, wszystkie szkoły policealne należą zatem do tej kategorii, jednak mogą mieć one status szkół dla dorosłych, jak również istnieć mogą takie placówki tego typu, w których proces nauczania zorganizowany jest analogicznie jak w szkołach (tj. przez 5 dni tygodniu) realizujących obowiązek szkolny. Nazywane są one potocznie szkołami policealnymi dla młodzieży. Przyjęte w art. 25 ust. 3 ustawy kryterium powoduje, że ten rodzaj publicznych szkół policealnych potraktowany został tak jak szkoły dla dorosłych, mimo że należy do placówek

6 Najwyższa Izba Kontroli, Kształcenie $w$ szkołach dla dorostych $w$ latach szkolnych 2013/2014-2015/2016, Warszawa 2017, s. 16. 
innego typu. Wprowadzone zróżnicowanie jest więc nieadekwatne do wskazanego w toku prac ustawodawczych motywu jego ustanowienia.

\section{Podsumowanie}

- Rozwiązania zawarte w art. 25 rządowego projektu ustawy o finansowaniu zadań oświatowych dotyczące dotowania szkół publicznych prowadzonych przez podmioty niebędące jednostkami samorządu terytorialnego (tzw. niesamorządowych szkół publicznych) wprowadzały pewne ich zróżnicowanie w porównaniu ze szkołami prowadzonymi przez jednostki samorządu terytorialnego. Zróżnicowanie to trudno byłoby uznać za naruszenie zasady równości wobec prawa (art. 32 Konstytucji). Szkoły publiczne prowadzone przez jednostki samorządu terytorialnego są bowiem jednostkami budżetowymi sektora finansów publicznych, a szkoły publiczne prowadzone przez inne podmioty - nie. Wobec różnego statusu prawnego sposób ustalania dotacji dla obu typów szkół nie musi być bezwzględnie taki sam. Ponadto projekt wprowadzał instytucję współczynnika zwiększającego, który uwzględniać miał przy obliczaniu dotacji dla publicznych szkół niesamorządowych wydatki ponoszone przez samorząd terytorialny na szkoły danego typu ponad kwotę naliczaną w części oświatowej subwencji ogólnej. Zróżnicowanie dotyczyło więc sposobu określania wielkości dotacji i było próbą realizacji założenia, zgodnie z którym „budżetowe” środki finansowe przeznaczone na nauczanie we wszystkich szkołach publicznych określonych typów są w przeliczeniu „na ucznia” równe bądź zbliżone. Kompleksowe wyjaśnienie kwestii zachowania w tym wypadku zasady równego traktowania wymagałoby przeprowadzenia dokładnej analizy skutków finansowych proponowanych regulacji w odniesieniu do szkół publicznych prowadzonych przez osoby fizyczne i prawne niebędące jednostkami samorządu terytorialnego, a konkretnie zastosowania współczynnika zwiększającego dotację dla tego typu szkół. To wykracza poza regulację zawartą w art. 25 projektu.

- Analiza postanowień zawartych w art. 25 opisanego wyżej projektu pod kątem zgodności z Konstytucją RP jest o tyle bezprzedmiotowa, że został on już uchwalony i ogłoszony w dniu 29 listopada 2017 r. w Dzienniku Ustaw, a istotnej zmianie uległ w toku prac ustawodawczych art. 25 ust. 3 ustawy.

- Marszałek Sejmu nie jest organem właściwym do rozpatrzenia „skargi” Publicznej Zaocznej Policealnej Szkoły Informatyki Cosinus w Łodzi. Działaniem, które może w zaistniałej sytuacji podjąć, byłoby przekazanie jej sejmowej Komisji Edukacji, Nauki i Młodzieży.

- Artykuł 25 ust. 3 ustawy o finansowaniu zadań oświatowych zawiera regulację, która może być traktowana jako naruszenie zasady równości wobec prawa oraz zakazu dyskryminacji. Przepis ten wyłącza bowiem w odniesieniu do 
szkół publicznych prowadzonych przez osoby fizyczne i prawne niebędące jednostkami samorządu terytorialnego, w których nie jest realizowany obowiązek szkolny lub obowiązek nauki, zastosowanie wspomnianego wcześniej współczynnika zwiększającego. Oznacza to, że szkoły tego rodzaju prowadzone przez jednostki samorządu terytorialnego mają jednoznacznie korzystniejszy status prawny, ponieważ dotacja na ich działalność ponad kwotę wynikającą z części oświatowej subwencji ogólnej z budżetu państwa dla jednostki samorządu terytorialnego nie będzie znajdowała żadnego „odpowiednika" w dotacji dla podobnych typów szkół prowadzonych przez inne podmioty. Oddziałuje to na realizację konstytucyjnego prawa do nauki i równego dostępu do wykształcenia. W toku prac ustawodawczych nie wskazano bliżej motywów, które uzasadniałyby wprowadzone zróżnicowanie, co przemawia za uznaniem je za niekonstytucyjne.

- Regulacja przyjęta w art. 25 ust. 3 wyżej opisanej ustawy dotyczy nie tylko szkół dla dorosłych (w rozumieniu ustawowym), co wskazywano w toku prac ustawodawczych jako podłoże wprowadzonych zmian w stosunku do projektu rządowego.

\section{Bibliografia}

Najwyższa Izba Kontroli, Kształcenie $w$ szkołach dla dorostych $w$ latach szkolnych 2013/2014-2015/2016, Warszawa 2017.

Słownik języka polskiego, t. VI, Warszawa 2007. 